\title{
NEUROPROTECTIVE EFFECT OF VITAMIN E IN A KAINATE-INDUCED RAT MODEL OF TEMPORAL LOBE EPILEPSY
}

\author{
Received April 9, 2013.
}

\begin{abstract}
Temporal lobe epilepsy (TLE) is known as the most common form of epilepsy in adults and as the type most resistant to treatment. Neuroprotective treatments are considered as a promising therapy for preventing and treating TLE. We investigated the possible neuroprotective effect of vitamin $\mathrm{E}$ in an intrahippocampal kainate model of TLE in rats. Kainate injection caused a higher incidence rate of seizures, and vitamin E pretreatment significantly attenuated this index. Intrahippocampal kainate also led to elevation of the malondialdehyde and nitrite/ nitrate levels and lowered superoxide dismutase (SOD) activity, while vitamin E significantly restored MDA and SOD indices. In addition, intrahippocampal kainate induced a significant degeneration of neurons in the $C A 1, C A 3$, and hilar regions of the hippocampus; vitamin $\mathrm{E}$ considerably attenuated these changes. Timm staining data demonstrated mossy fiber sprouting (MFS) in the dentate gyrus of kainate-lesioned rats, and vitamin E significantly lowered the MFS intensity. Our data suggest that vitamin E pretreatment is capable of attenuating seizures and inhibiting hippocampal neuronal loss and MFS in the kainate-induced model of TLE. A part of the beneficial vitamin E effects is due to its potential to mitigate oxidative stress.
\end{abstract}

Keywords: vitamin E, temporal lobe epilepsy, kainate, mossy fiber sprouting, oxidative stress, hippocampus.

\section{INTRODUCTION}

Epilepsy is a widespread chronic brain disorder with recurrent seizures due to enhanced and synchronized activity of cerebral neurons [1]. Temporal lobe epilepsy (TLE) is a prevalent form of epilepsy in adults, usually accompanied by hippocampal sclerosis, neurodegeneration, and extense reorganization of hippocampal circuits [2]. Subsequent development of chronic epilepsy, characterized by spontaneous recurrent seizures, is observed [3]. In about $40 \%$ of patients with TLE, seizures are refractory to current medicines [1]. Although existing medications can symptomatically suppress seizures, there is little evidence that existing antiepileptic drugs could effectively correct the underlying abnormal processes leading to epilepsy or alter its development [4, 5]. Thus, novel treatment approaches are strongly required to prevent or even reverse the cellular and molecular mechanisms of epileptogenesis [6]. Neuroprotective strategies are increasingly considered as a promising therapy for preventing and treating TLE [3]. A

\footnotetext{
${ }^{1}$ Neurophysiology Research Center, Shahed University, Tehran, Iran. Correspondence should be addressed to M. Roghani (e-mail: mehjour@yahoo.com).
}

well-characterized animal model of TLE is based on intrahippocampal injections of the excitotoxic glutamate analog kainate in rodents.

The vitamin E family, including tocotrienols and tocopherols, is constituted by compounds crucially essential for living cells; these compounds are known as one of the most effective antioxidants found in biological systems [7, 8]. Vitamin $\mathrm{E}$ is known as an essential nutrient for animals and humans and as a potent antioxidant effectively reducing the level of free radicals [8]. Since excitotoxic stimulation in epilepsy induces excessive production of reactive oxygen species (ROSs) leading to oxidative stress [9], vitamin E can act as a chain-breaking antioxidant protecting the cell membranes against oxidative damage [10]. In animals, vitamin $\mathrm{E}$ can inhibit seizures induced by ferrous chloride, hyperbaric oxygen, and penicillin, where ROS production may play a very important role in the development of seizures [11-13]. This vitamin decreases the frequency of penicillin-induced epileptic manifestations [11]. In addition, vitamin $\mathrm{E}$ exerts a protective effect against pentylenetetrazol-induced toxicity by inhibiting production of free radicals and by supporting the antioxidant redox system [14]. Vitamin E was also shown to reduce kainate-induced neuronal damage in the hippocampus [15]. 
Until now, there is no evidence on the neuroprotective effect of vitamin $\mathrm{E}$ in the kainateinduced model of TLE. Therefore, we decided to investigate whether vitamin $\mathrm{E}$ ameliorates neurodegeneration, mossy fiber sprouting (MFS), and oxidative stress under conditions of kainate-induced TLE in rats.

\section{METHODS}

All experiments were performed on adult male Wistar rats (280-320 g; $n=48$ ) (Pasteur's Institute, Tehran, Iran). The animals were housed three to four per cage in a temperature-controlled colony room under $12 / 12$ light/dark cycle with food and water available $a d$ libitum.

Experimental Procedure. Rats were randomly divided into four equal-size groups, sham-operated (Sh), vitamin E-treated and sham-operated $(\mathrm{Sh}+\mathrm{v} . \mathrm{E})$, kainate $(\mathrm{K})$, and kainate-injected + vitamin E-treated $(\mathrm{K}+\mathrm{v} . \mathrm{E})$. For intrahippocampal injections, rats were anesthetized with chloral hydrate $(350 \mathrm{mg} / \mathrm{kg})$ and placed into the stereotaxic frame (Stoelting Co., USA) with the incisor bar set at $3.3 \mathrm{~mm}$ below the interaural line. The dorsal surface of the skull was exposed, and a burr hole was drilled in the skull using the following stereotaxic coordinates [16]: anteroposterior (AP), 4.3 $\mathrm{mm}$ caudal to the bregma; $4.2 \mathrm{~mm}$ lateral to the midline (right side), and 4.0-4.2 $\mathrm{mm}$ ventral to the surface of the skull. A 5-ml microsyringe filled with normal saline containing $0.8 \mathrm{mg} / \mathrm{ml}$ of kainate was placed over the burr hole, and kainate solution was injected at a rate of $1 \mathrm{ml} / \mathrm{min}$. Kainic acid (Sigma-Aldrich, USA) was dissolved in cold normal saline just prior to surgery. The Sh group received an equivalent volume of normal saline at the same stereotaxic coordinates. The microsyringe was slowly withdrawn after $5 \mathrm{~min}$, and the scalp wound was sutured. The $\mathrm{Sh}+$ v.E group received vitamin E (alpha tocopherol; Sigma-Aldrich, USA) perorally using a gavage needle at a dose of $200 \mathrm{mg} / \mathrm{kg}$ - day starting 1 week before surgery; the last treatment was realized $1 \mathrm{~h}$ before surgery. Vitamin E was diluted in propylene glycol (Merck, Germany). The dose of vitamin E was chosen according to the data of previous reports on its antiepileptic activity $[17,18]$ and our pilot study.

Behavioral Assessment of Seizures. All animals were assessed for seizure activity during the first $24 \mathrm{~h}$ and at the 5 th week post-surgery, $4 \mathrm{~h}$ per day for 5 consecutive days according to the Racine's point classification. Zero corresponded to no reaction; 1, stereotypic mounting, eye blinking, and/or mild facial clonus; 2 , head nodding and/or multiple facial clonus; 3 , myoclonic jerks in the forelimbs; 4, clonic convulsions in the forelimbs with rearing, and 5, generalized clonic convulsions and loss of balance [19].

\section{Assessment of Oxidative Stress Markers}

Measurement of the Hippocampal Malondialdehyde (MDA) Concentration. The rats were anesthetized with diethyl ether and decapitated. Their hippocampi were isolated, blotted dry, weighed, and prepared as a $5 \%$ tissue homogenate in ice-cold $0.9 \%$ saline solution. After centrifugation $\left(1,000 \mathrm{~g}, 4^{\circ} \mathrm{C}, 10 \mathrm{~min}\right)$, the supernatant was aliquoted and stored at $-70^{\circ} \mathrm{C}$ until assayed. The concentration of MDA (used as a marker of lipid peroxidation) was calculated by measuring thiobarbituric acid-reactive substances (TBARSs) in the supernatant as described previously [20]. Briefly, trichloroacetic acid and a TBARS reagent were added to aliquots of the supernatant, which were subsequently mixed and incubated at $90^{\circ} \mathrm{C}$ for $80 \mathrm{~min}$. After cooling on ice, the samples were centrifuged at $1,000 \mathrm{~g}$ for $10 \mathrm{~min}$, and the absorbance of the supernatant was measured spectrophotometrically at $532 \mathrm{~nm}$. The results of TBARS measurements were expressed as MDA equivalents, using tetraethoxypropane as the standard.

Assay of the Hippocampal Nitrite/Nitrate Concentration. Supernatant nitrite/nitrate content was assayed by the Griess method as described before [21]. The NO compound is characterized by a short half-life and is rapidly converted to the stable end products nitrate and nitrite. In this assay, color development with the Griess reagent (sulfanilamide and $\mathrm{N}$-naphthyl ethylenediamine) in an acidic medium was assessed. The absorbance was measured using a spectrophotometer at $540 \mathrm{~nm}$.

Measurement of Hippocampal Superoxide Dismutase ( SOD) Activity. Activity of SOD was measured as previously reported [21]. Briefly, the supernatant was incubated with xanthine and xanthine oxidase in potassium phosphate buffer $\left(\mathrm{pH} 7.8,37^{\circ} \mathrm{C}\right)$ for $40 \mathrm{~min}$, and then nitro blue tetrazolium (NBT) was added. Thereafter, blue formazan was monitored spectrophotometrically at $550 \mathrm{~nm}$. The amount of protein that inhibited NBT reduction to $50 \%$ maximum was defined as one nitrite unit (NU) of SOD activity.

Protein Assay. The protein content of the supernatant was measured by the Bradford method, using bovine serum albumin (Sigma Chemical, USA) as the standard [22]. 
Histological Studies. Four or five animals of each group were randomly used for histological assessment. The rats were deeply anesthetized with a high dose of ketamine $(150 \mathrm{mg} / \mathrm{kg})$ and perfused through the ascending aorta with $50 \mathrm{ml}$ of heparinized normal saline followed by $100 \mathrm{ml}$ of a sulfide solution $(1.2 \%$ $\mathrm{Na}_{2} \mathrm{~S}$ and $1.0 \% \mathrm{NaH}_{2} \mathrm{PO}_{4}$ ) and then with $100-150 \mathrm{ml}$ of a fixative solution containing $4 \%$ paraformaldehyde in $0.1 \mathrm{M}$ phosphate buffer (PB, $\mathrm{pH}$ 7.4). Following perfusion, the brains were removed from the skull; hippocampal blocks were prepared and immersed in $30 \%$ sucrose in $\mathrm{PB}$ at $4^{\circ} \mathrm{C}$ for $2-3$ days. Then, $40-\mathrm{mm}-$ thick sections were cut on a freezing microtome (Leica, Germany) and collected in 0.1 M PB. Every second section was Nissl-stained with $0.1 \%$ cresyl violet (Sigma, USA), and alternate sections were used for Timm staining. In Nissl-stained sections, neuronal loss was quantified in the $C A 1, C A 3$, and hilar regions of the hippocampus in at least three sections at a level range between 3.6 and $-4.3 \mathrm{~mm}$ from the bregma using an image capturing and analysis system (Bel Engineering, Italy). The process was repeated at least two times for each section; its average was calculated and taken as the final value. Counting was done blind to the treatments received.

To visualize MFS in the inner molecular layer of the dentate gyrus (DG) that accompanies epileptogenesis, we employed a modified Timm histological procedure to label zinc-containing axons of the granule cells [23]. The slices were subsequently immersed in $100 \%$ alcohol for $5 \mathrm{~min}$, in $70 \%$ alcohol for $5 \mathrm{~min}$, in distilled water for $10 \mathrm{~min}$, and then stayed in the dark under continuous agitation for $60 \mathrm{~min}$ in the Timm's working solution of the following composition: $60 \mathrm{ml}$ of $50 \%$ gum Arabic, $10 \mathrm{ml}$ of $2 \mathrm{M}$ sodium citrate buffer $(\mathrm{pH} 3.7), 30 \mathrm{ml}$ of $5.6 \%$ hydroquinone, and $0.5 \mathrm{ml}$ of $17 \%$ silver nitrate solution. The staining process was terminated with $2 \%$ sodium acetate, and the unreacted silver ions were removed with $5 \%$ sodium thiosulfate. The sections were counterstained with $0.1 \%$ cresyl violet, dehydrated, and coverslipped. The assessment of MFS (as a Timm index) was obtained from the value of the area of Timm granules divided by the length of the DG [24]. The Timm index for each animal was the mean of three sections. All procedures and analyses were done blind to the treatments.

Statistical Analysis. All statistical analyses were performed using SigmaStat software (version 3.5). Numerical values were expressed as means \pm s.e.m. To compare the experimental groups, non-behavioral data were analyzed using one-way ANOVA followed by the Tukey's post hoc test. Seizure-related behavioral data were analyzed using the non-parametric KruskalWallis test. The percentage of rats with seizures was examined by the $\chi^{2}$ test. In all analyses, the null hypothesis was rejected at a $P$ level below 0.05 .

\section{RESULTS}

Behavioral Assessment of Seizure Activity. Sham and $\mathrm{Sh}+\mathrm{v}$.E groups showed no signs of seizure activity during the first $24 \mathrm{~h}$ post-surgery interval and/or after 4 weeks. In contrast, all rats $(100 \%)$ in the $\mathrm{K}$ group exhibited high scores of seizures during the first $24 \mathrm{~h}$ post-surgery, and $58.3 \%$ of them had seizures at the 5 th week. At the same time, rats injected with kainate and pretreated with vitamin $\mathrm{E}(\mathrm{K}+\mathrm{v} . \mathrm{E}$ group) exhibited noticeably lower seizure activity as compared to the $\mathrm{K}$ group. In this respect, only 41.6 and $16.7 \%$ of such rats demonstrated seizures during the first $24 \mathrm{~h}$ and at the 5th week post-surgery, and this difference was statistically significant $v s$ the $\mathrm{K}$ group $(P<0.05$ and $P<0.01$, respectively; Table 1 ).

Oxidative Stress Markers. Vitamin E pretreatment of the $\mathrm{Sh}+\mathrm{v}$.E group caused no significant change in the hippocampal levels of MDA and nitrite/nitrate and activity of SOD as compared to the Sh group. In contrast, the $\mathrm{K}$ group showed a significant elevation of the MDA $(P<0.01)$ and nitrite/nitrate $(P<0.05)$ con-

TABLE 1. Numbers of Animals with Seizure Activity at Different Post-Surgery Intervals

Кількість тварин, у яких була виявлена судомна активність у межах різних післяопераційних інтервалів

\begin{tabular}{l|cc}
\hline \multirow{2}{*}{ Experimental groups } & \multicolumn{2}{c}{ Numbers of rats with seizures } \\
\cline { 2 - 3 } & within an initial 24-h interval & at the 5th week \\
\hline Sham (Sh) & $0 / 12(0 \%)$ & $0 / 12(0 \%)$ \\
Sham+Vitamin E (Sh + v.E) & $0 / 12(0 \%)$ & $0 / 12(0 \%)$ \\
Kainate (K) & $12 / 12(100 \%)$ & $7 / 12(58.3 \%)$ \\
Kainate + Vitamin E (K + v.E) & $5 / 12(41.6 \%)^{*}$ & $2 / 12(16.7 \%)^{* *}$ \\
\hline
\end{tabular}

Footnotes. Normalized numbers, $\%$, are shown in parentheses. ${ }^{*} P<0.05$ and ${ }^{*} P<0.01$ as compared to the $\mathrm{K}$ group. 


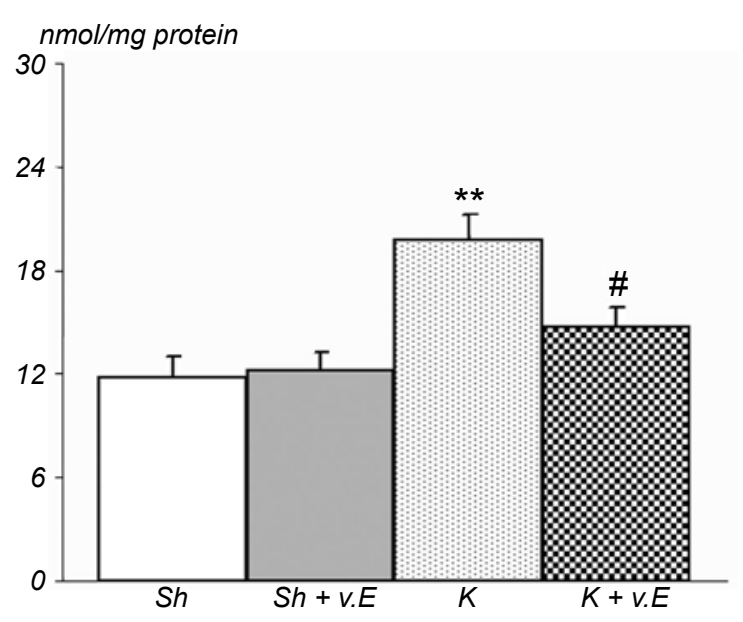

F i g. 1. Mean malondiadehyde (MDA) concentration (vertical scale, $\mathrm{nmol} / \mathrm{mg}$ protein) in the hippocampal homogenate obtained from animals of different groups (shown below). ${ }^{* *} P<0.01$ in comparison with the sham group; ${ }^{\#} P<0.05$ in comparison with the kainate group $(n=6-7)$.

Р и с. 1. Середня концентрація малонового альдегіду (вертикальна шкала - нмоль/мг протеїну) у гіпокампальному гомогенаті, отриманому від тварин різних груп.

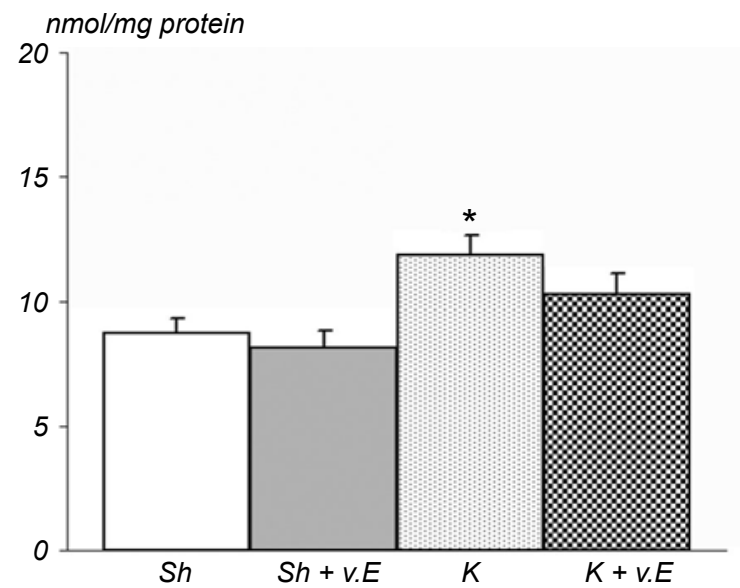

F i g. 2. Nitrite/nitrate content in the hippocampal homogenate. $* P<0.05$ in comparison with the sham group. Other designations are similar to those in Fig. 1.

Р и с. 2. Вміст нітритів/нітратів у гіпокампальному гомогенаті.

tents and a significant reduction of the SOD activity $(P<0.05)$. The pretreatment of the $\mathrm{K}$ group with vitamin $\mathrm{E}(\mathrm{K}+\mathrm{v} . \mathrm{E})$ significantly attenuated the increased MDA concentration $(P<0.05)$ and enhanced the activity of SOD $(P<0.05)$ but did not significantly change the nitrite content. At the same time, the level of nitrite/nitrate was slightly and non-significantly lower in the $\mathrm{K}+\mathrm{v}$.E group as compared to the $\mathrm{K}$ group (Figs. 1-3).

Cytoarchitecture of the Hippocampus (Nissl Staining). In this study, the numbers of neurons per unit area

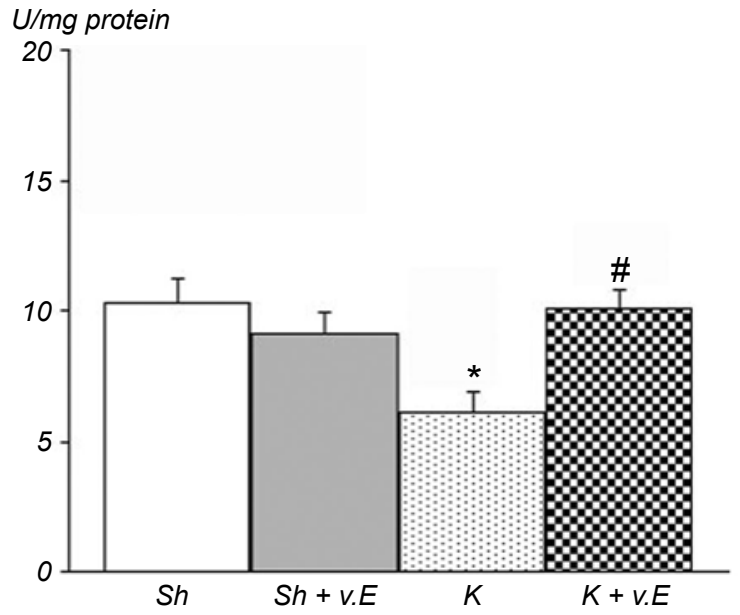

F i g. 3. Superoxide dismutase (SOD) activity (vertical scale, U/mg protein) in the hippocampal homogenate. ${ }^{*} P<0.05$ in comparison with the sham group; ${ }^{\#} P<0.05$ in comparison with the kainate group. Other designations are similar to those in Figs. 1 and 2.

Р и с. 3. Активність супероксиддисмутази (вертикальна шкала, од./мг протеїну) в гіпокампальному гомогенаті.

in the $C A 1, C A 3$, and hilar regions of the hippocampus were counted and compared among groups (Fig. 4). Our results showed that vitamin $\mathrm{E}$ pretreatment of sham animals $(\mathrm{Sh}+\mathrm{v} . \mathrm{E})$ produced no significant shift in this regard. In contrast, intrahippocampal injections of kainate induced dramatic statistically significant degeneration of neurons and reduction of their density in the $C A 1$ $(P<0.05), C A 3(P<0.005)$, and hilar $(P<0.01)$ regions of the hippocampus $v s$ the Sh group. In this regard, neurodegeneration in the hippocampus was typified by an apparent cell loss in the dentate gyrus and hilus and considerable thinning of cell layers in the $C A 1$ and $C A 3$ regions and dentate gyrus of rats of the $\mathrm{K}$ group. This led to increase in the granule cell dispersion (GCD) and displacement of their layer; the latter was 2 to 3 times broader in the upper border. Furthermore, vitamin E pretreatment of kainate-injected rats significantly attenuated the respective changes in the $C A 1$ ( $P$ $<0.05), C A 3(P<0.01)$, and hilar $(P<0.05)$ regions as compared to the $\mathrm{K}$ group. These data suggest that vitamin $\mathrm{E}$ pretreatment can protect and rescue the neurons of hippocampal regions against kainate-induced neurotoxicity.

Timm Histochemistry. Mossy fibers from granule cells in the dentate gyrus undergo reorganization of their terminal projections in both epilepsy in humans and animal models of epilepsy [24]. Timm staining is a well-accepted method for visualization of zinccontaining neuronal elements. Our observations concerning zinc histochemistry in the hippocampus are in 


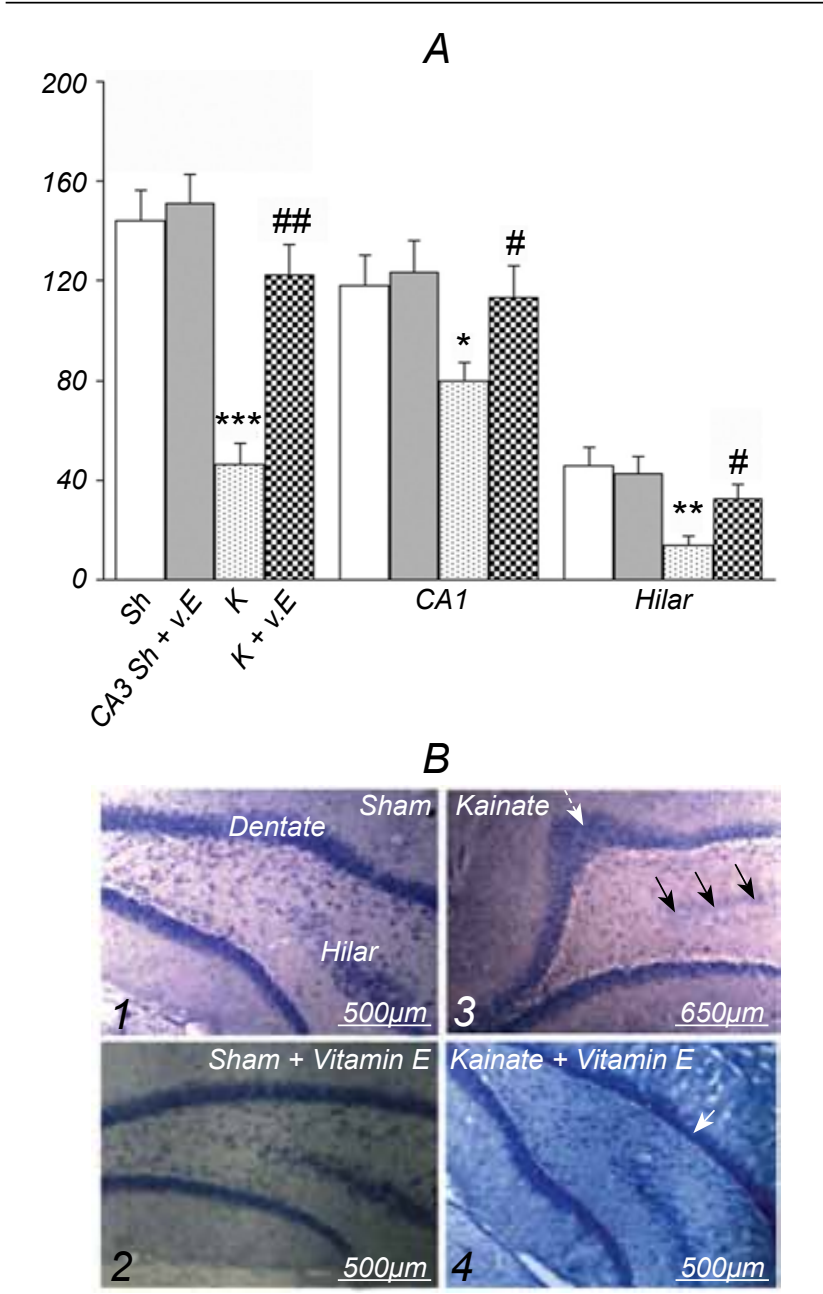

F i g. 4. Neurodegenerative changes in kainate-injected rats. A) Numbers of Nissl-stained neurons in different areas of the hippocampus (designations are similar to those in Fig. 1). B) photomicrographs (1-4) of coronal sections through the dentate region from animals of four groups: sham-operated (Sh), vitamin T-treated and sham-operated (Sh + v.E), kainate $(\mathrm{K})$, and vitamin E-pretreated kainate $(\mathrm{K}+\mathrm{v} . \mathrm{E})$, respectively. Severe reduction in the number of neurons in the hilar region (solid filled arrows) and neuronal dispersion in the upper blade (dotted open arrow) were observed in the $\mathrm{K}$ group, but no such changes were prominent in the $\mathrm{K}+\mathrm{v} . \mathrm{E}$ group. $* P<0.05, * * P<0.01$, and $* * * P<0.005$ in comparison with the Sh group; ${ }^{\#} P<0.05$ and ${ }^{\# \#} P<0.01$ in comparison with the $\mathrm{K}$ group $(n=4-5)$.

Р и с. 4. Нейродегенеративні зміни у щурів, ін'єкованих каїнатом.

agreement with the literature data [25]. In our study, kainate-induced MFS was demonstrated by the Timm method at the 5th week post-surgery (Fig. 5). Synaptic terminals of mossy fibers were selectively labeled due to their high zinc content. In the Sh group, little sprouting was present in the DG molecular layer. In contrast, Timm staining showed MFS that extended into the dentate supragranular layer in the $\mathrm{K}$ group. In
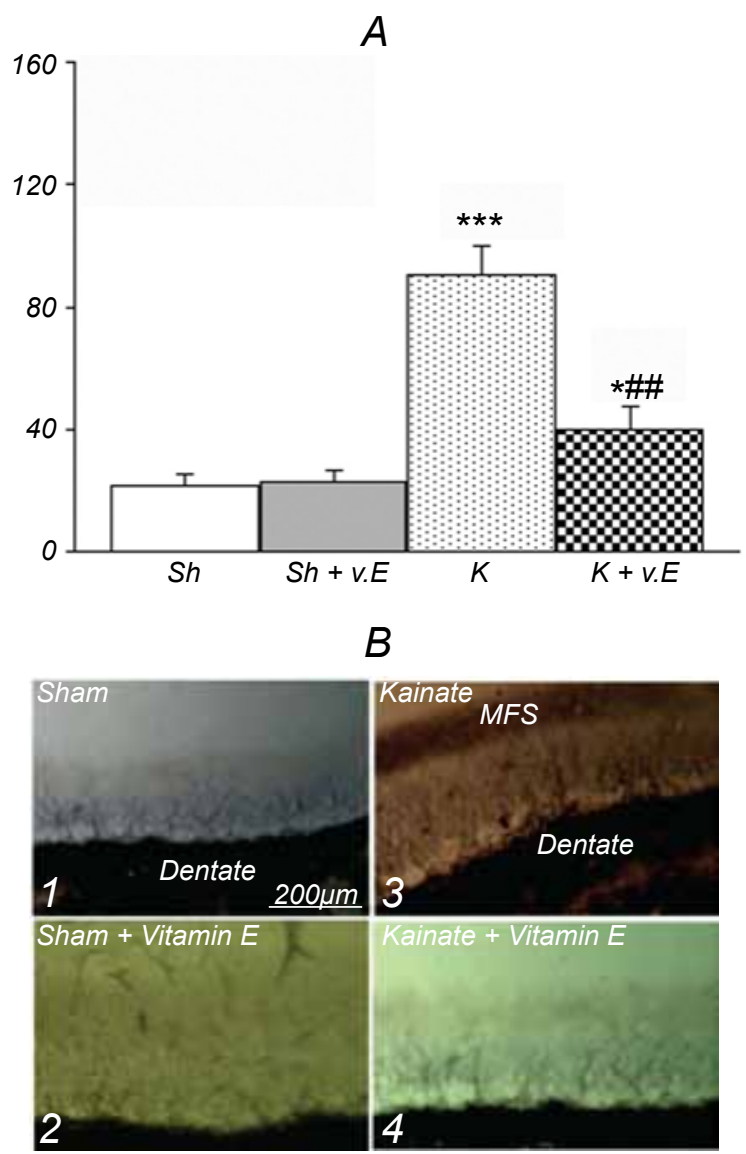

F i g. 5. Mossy fiber sprouting (MFS) in kainate-injected rats. A) Timm index in different groups as an indicator of MFS; B) photomicrographs through the dentate region, which show MFS revealed by Timm staining in different groups (1-4). ${ }^{*} P<0.05$ and ${ }^{* * *} P<0.005$ in comparison with the sham group; ${ }^{\#} P<0.01$ in comparison with the kainate group $(n=4-5)$.

Р и с. 5. Спраутинг моховитих волокон у щурів після ін'єкцій каїнату.

the vitamin E-pretreated group ( $\mathrm{K}+\mathrm{v} . \mathrm{E})$, supragranular MFS was less intense and more dispersed, though it was still denser than in the Sh group. We further compared the average width and Timm staining density (characterized by the Timm index) between the $\mathrm{K}$ and $\mathrm{K}+\mathrm{v} . \mathrm{E}$-pretreated groups and found that vitamin E pretreatment significantly reduced the MFS width and staining density $(P<0.01)$. These data indicate that vitamin $\mathrm{E}$ is able to restrain kainate-induced MFS.

\section{DISCUSSION}

Temporal lobe epilepsy is a chronic and intractable neurological disorder with recurrent seizures; it results from the development of abnormal recurrent excitatory 
and/or inhibitory circuits. Recurrent excitation and the development of seizures are also associated with aberrant MFS in the hippocampus [26]. Intracerebral injections of kainate into the $C A 3$ region of the hippocampus cause initiation or intensification of epileptic seizures. These seizures are followed by cell loss similar to that observed in patients suffering from TLE [27]. Considering this, kainate-induced brain damage has been routinely used for modeling TLE and excitotoxic neurodegenerative disorders [28]. Accumulating evidence indicates that hippocampal oxidative stress is noticeably involved in kainateinduced neurotoxicity [29]. Kainate in general acts through three classes of ionotropic receptors, namely NMDA (N-methyl-D-aspartate), AMPA (alpha-amino3-hydroxy-5-methyl-4-isoxazole propionic acid), and kainate receptors. Among different ionotropic glutamate receptors, kainic acid receptors (KARs), containing the GluR6 subunit, are important in synaptic transmission, as well as in the epileptogenic effects of kainate [30]. Therefore, these receptors are expected to be overexpressed in the $C A 3$ region in intrahippocampal kainate-induced TLE. This factor promotes the development of seizures and ensues pathology, including degeneration of hippocampal neurons and an aberrant MFS in the inner molecular layer of the DG [24].

In our study, a massive neuronal loss was found in the $C A 1, C A 3$, and hilar regions in the $\mathrm{K}$ animal group. Typical aberrant mossy fibers invading into the granule cell layer and granule cell-inner molecular layer in the hippocampus of these rats were noticed; this is consistent with observations in previous studies [24]. Kainate injection into the hippocampus led to degeneration of $C A 3$ pyramidal neurons and dentate hilar cells. The granule cell axons (known as mossy fibers), originating from the DG, lose their postsynaptic target cells and sprout into the inner molecular layer. These pathological changes cause the formation of functional recurrent excitatory circuits between granule cells that may contribute to recurrent seizures in our study $[24,31]$.

Following kainate injection, intensification of oxidative stress occurs [32], and the development of seizures is also associated with such stressogenic conditions [33]. On the other hand, a deficiency of the antioxidant redox systems can exacerbate the etiology of epilepsy [34]. Increased lipid peroxidation in the brain was reported in pentylenetetrazol-induced epilepsy in rats [35]. Moreover, seizure activity is related to increased levels of free radicals and reduced activ- ity of the antioxidant defense mechanisms [17]. Thus, epileptiform states with seizures are associated with an imbalance between oxidant and antioxidant defense mechanisms.

Vitamin E as a lipophilic antioxidant protects the membranes from being oxidatively damaged by free radicals and attenuates lipid peroxidation in the brain [36]. Although the role of inflammation in the used model of TLE was not evaluated in our present study, vitamin E may also exerts certain protective effect against seizures in kainate-injected rats through its anti-inflammatory activity [37]. However, concepts on the role of anti-inflammatory agents in progression and prevention of epilepsy are controversial [38, 39]. The kainate-induced seizure rat model is accompanied by inflammation with increased production of certain prostaglandins, such as prostaglandin E2; this follows an enhancement in the mRNA levels of cyclooxygenase 2 and prostaglandin E2 synthase (PGEs) in the brain tissue. Anti-inflammatory agents can reduce the severity of the corresponding conditions [40]. In parallel with this fact, it was shown that kainate-induced excitotoxicity through induction of matrix metalloproteinases leads to selective neuronal death and neuroinflammation in the hippocampus; inhibitors of such enzymes can attenuate the ensuing neuronal damage, and this could be therapeutically relevant in the related neurological disorders [41]. On the other hand, it was mentioned above that vitamin $E$ is capable of manifesting anti-inflammatory properties [42]; this aspect needs further investigation.

The neuroprotective and antiapoptotic potential of vitamin E reduces the detrimental action of neurotoxins and/or excitotoxic agents on neurons [43, 44]. In our study, due to the neuroprotective effect of vitamin E, we observed lower degrees of neuronal loss and MFS in the $\mathrm{K}+\mathrm{v} . \mathrm{E}$ group than those in the $\mathrm{K}$ one. Previous studies demonstrated that vitamin E could ameliorate pentylenetetrazol-induced seizure activity by inhibiting production of free radicals and supporting the antioxidant redox system [45]. In addition, the neuroprotective anti-oxidative stress effect of vitamin E with respect to hippocampal neurons was shown in the cell culture [46]. In our study, pretreatment with vitamin $\mathrm{E}$ in the kainate-injected group attenuated oxidative stress burden, as was evident from a significantly lower level of MDA and higher activity of SOD in the hippocampal tissue, and this was associated with less severe seizure activity. Results of our study clearly suggest that vitamin E counteracts kainate-induced epilepsy (at least partly) by functioning as an anti-oxidant. 
Therefore, pretreatment with vitamin $\mathrm{E}$ attenuates seizure activity and inhibits hippocampal neuronal loss and MFS in the kainate-induced rat model of TLE, and its beneficial effect is partly due to its ability to mitigate oxidative stress.

Acknowledgments. This work was financially funded and supported by a research grant from Shahed University (Tehran, Iran). The authors would also like to thank Morteza Ashouri for his valuable technical assistance.

Procedures involving animals were conducted in conformity with NIH Guidelines for the Care and Use of Laboratory Animals. In this study, all efforts were made to minimize the number of animals used and their suffering.

The authors, Z. Kiasalari, M. Khalili, and M. Roghani, confirm that they have no conflict of interests.

\section{3. Кіасаларі ${ }^{1}$, М. Халілі ${ }^{1}$, М. Роган ${ }^{1}$}

\section{НЕЙРОПРОТЕКТОРНИЙ ЕФЕКТ ВІТАМІНУ Е В УМО- ВАХ КАЇНАТІНДУКОВАНОЇ МОДЕЛІ «СКРОНЕВОЇ» ЕПІЛЕПСІЇ У ЩУРІВ}

\author{
${ }^{1}$ Нейрофізіологічний дослідницький центр Університету \\ „Шахед”, Тегеран (Іран). \\ P е 3 ю м е
}

«Скронева» епілепсія (CE) - найпоширеніша форма епілепсії у дорослих, причому найбільш резистентна до лікування. Як перспективний напрямок у профілактиці та лікуванні СЕ розглядаються підходи, засновані на нейропротекції. Ми досліджували можливий нейропротекторний ефект вітаміну Е на „каїнатній” моделі СЕ у щурів (інтрагіпокампальне введення каїнату). Такі ін'єкції зумовлювали підвищену ймовірність прояву судом, а попереднє курсове введення вітаміну Е істотно знижувало відповідний індекс. Ін'єкції каїнату також призводили до зростання рівнів малонового альдегіду та нітритів/нітратів і падіння активності супероксиддисмутази; під впливом вітаміну Е відповідні значення нормалізувалися. До того ж, інтрагіпокампальні введення каїнату викликали істотну дегенерацію нейронів у зонах $C A 1$ та $C A 3$ і хілусі гіпокампа, а вітамін Е значно обмежував ці зміни. Результати забарвлення за Тіммом продемонстрували наявність феномену спраутинга моховитих волокон у зубчастій звивині щурів після введення каїнату; вітамін Е істотно зменшував інтенсивність даного процесу. Наші результати дозволяють нам вважати, що попередня дія вітаміну Е сприяє зменшенню інтенсивності судом, знижує загибель нейронів у гіпокампі та обмежує спраутинг в умовах каїнатної моделі СЕ. Позитивний ефект вітаміну Е частково зумовлений його здатністю послаблювати оксидативний стрес.

\section{REFERENCES}

1. G. Curia, D. Longo, G. Biaginiand, et al., "The pilocarpine model of temporal lobe epilepsy," J. Neurosci. Methods, 172, No. 2, 143-157 (2008).

2. H. Jokeit and M. Schacher, "Neuropsychological aspects of type of epilepsy and etiological factors in adults," Epilepsy Behav., 5, Suppl. 1, S14-20 (2004).

3. M. M. Acharya, B. Hattiangady, and A. K. Shetty, "Progress in neuroprotective strategies for preventing epilepsy," Prog. Neurobiol., 84, No. 4, 363-404 (2008).

4. M. A. Dichter, "Models of epileptogenesis in adult animals available for antiepileptogenesis drug screening," Epilepsy Res., 68, No. 1, 31-35 (2006).

5. H. Stefan, F. H. Lopes da Silva, W. Loscherand, et al., "Epileptogenesis and rational therapeutic strategies," Acta Neurol. Scand., 113, No. 3, 139-155 (2006).

6. W. Loscher and D. Schmidt, "New horizons in the development of antiepileptic drugs: Innovative strategies," Epilepsy Res., 69, No. 3, 183-272 (2006).

7. S. Asha Devi, “Aging brain: prevention of oxidative stress by vitamin E and exercise," Sci. World J., 9, 366-372 (2009).

8. M. L. Colombo, "An update on vitamin E, tocopherol and tocotrienol - perspectives," Molecules, 15, No. 4, 2103-2113 (2010).

9. R. M. Freitas, S. M. Vasconcelos, F. C. Souzaand, et al., "Oxidative stress in the hippocampus after pilocarpineinduced status epilepticus in Wistar rats," FEBS J., 272, No. 6, 1307-1312 (2005).

10. M. Kotegawa, M. Sugiyama, T. Shojiand, et al., "Effect of alpha-tocopherol on high energy phosphate metabolite levels in rat heart by 31P-NMR using a Langendorff perfusion technique," J. Mol. Cell Cardiol., 25, No. 9, 1067-1074 (1993).

11. M. Ayyildiz, M. Yildirim, and E. Agar, "The effects of vitamin E on penicillin-induced epileptiform activity in rats," Exp. Brain Res., 174, No. 1, 109-113 (2006).

12. S. L. Levy, W. M. Burnham, A. Bishaiand, et al., "The anticonvulsant effects of vitamin E: a further evaluation," Can. J. Neurol. Sci., 19, No. 2, 201-203 (1992).

13. M. Ayyildiz, M. Yildirim, and E. Agar, "The involvement of nitric oxide in the anticonvulsant effects of alpha-tocopherol on penicillin-induced epileptiform activity in rats," Epilepsy Res., 73, No. 2, 166-172 (2007).

14. A. Armagan, S. Kutluhan, M. Yilmazand, et al., "Topiramate and vitamin E modulate antioxidant enzyme activities, nitric oxide and lipid peroxidation levels in pentylenetetrazolinduced nephrotoxicity in rats," Basic Clin. Pharmacol. Toxicol., 103, No. 2, 166-170 (2008).

15. G. G. Ortiz, Y. Sanchez-Ruiz, D. X. Tanand, et al., "Melatonin, vitamin $\mathrm{E}$, and estrogen reduce damage induced by kainic acid in the hippocampus: potassium-stimulated GABA release," J. Pineal Res., 31, No. 1, 62-67 (2001).

16. G. Paxinos and C. Watson, The Rat Brain in Stereotaxic Coordinates, Acad. Press, San Diego (1986).

17. R. Tome Ada, P. M. Ferreira, and R. M. Freitas, "Inhibitory action of antioxidants (ascorbic acid or alpha-tocopherol) on seizures and brain damage induced by pilocarpine in rats," Arq. Neuropsiquiatr., 68, No. 3, 355-361 (2010).

18. A. R. Tome, D. Feng, and R. M. Freitas, "The effects of alpha-tocopherol on hippocampal oxidative stress prior to in pilocarpine-induced seizures," Neurochem. Res., 35, No. 4, 580-587 (2010). 
19. R. Racine, V. Okujava, and S. Chipashvili, "Modification of seizure activity by electrical stimulation. 3. Mechanisms," Electroencephalogr. Clin. Neurophysiol., 32, No. 3, 295-299 (1972).

20. M. Roghani and T. Baluchnejadmojarad, "Chronic epigallocatechin-gallate improves aortic reactivity of diabetic rats: underlying mechanisms," Vascul. Pharmacol., 51, Nos. 2/3, 84-89 (2009).

21. T. Baluchnejadmojarad and M. Roghani, "Chronic epigallocatechin-3-gallate ameliorates learning and memory deficits in diabetic rats via modulation of nitric oxide and oxidative stress," Behav. Brain Res., 224, No. 2, 305-310 (2011).

22. M. M. Bradford, "A rapid and sensitive method for the quantitation of microgram quantities of protein utilizing the principle of protein-dye binding," Anal. Biochem., 72, 248-254 (1976).

23. N. Karoly, A. Mihaly, and E. Dobo, "Comparative immunohistochemistry of synaptic markers in the rodent hippocampus in pilocarpine epilepsy," Acta Histochem., 113, No. 6, 656-662 (2011).

24. Z. Wu, Q. Xu, L. Zhangand, et al., "Protective effect of resveratrol against kainate-induced temporal lobe epilepsy in rats," Neurochem. Res., 34, No. 8, 1393-1400 (2009).

25. C. H. Liu, Y. W. Lin, N. Y. Tangand, et al., "Neuroprotective effect of Uncaria rhynchophylla in kainic acid-induced epileptic seizures by modulating hippocampal mossy fiber sprouting, neuron survival, astrocyte proliferation, and S100B expression," Evid. Based Complement. Alternat. Med., 2012, 194790 (2012).

26. A. K. Sharma, R. Y. Reams, W. H. Jordanand, et al., "Mesial temporal lobe epilepsy: pathogenesis, induced rodent models and lesions," Toxicol. Pathol., 35, No. 7, 984-999 (2007).

27. Y. Ben-Ari and R. Cossart, "Kainate, a double agent that generates seizures: two decades of progress," Trends Neurosci., 23, No. 11, 580-587 (2000).

28. G. Sperk, "Kainic acid seizures in the rat," Prog. Neurobiol., 42, No. 1, 1-32 (1994).

29. E. J. Shin, K. H. Ko, W. K. Kimand, et al., "Role of glutathione peroxidase in the ontogeny of hippocampal oxidative stress and kainate seizure sensitivity in the genetically epilepsyprone rats," Neurochem. Int., 52, No. 6, 1134-1147 (2008).

30. C. Mulle, A. Sailer, I. Perez-Otanoand, et al., "Altered synaptic physiology and reduced susceptibility to kainate-induced seizures in GluR6-deficient mice," Nature, 392, No. 6676, 601-605 (1998).

31. A. K. Shetty and B. Hattiangady, "Restoration of calbindin after fetal hippocampal CA3 cell grafting into the injured hippocampus in a rat model of temporal lobe epilepsy," Hippocampus, 17, No. 10, 943-956 (2007).

32. S. Y. Li, Y. H. Jia, W. G. Sunand, et al., "Stabilization of mitochondrial function by tetramethylpyrazine protects against kainate-induced oxidative lesions in the rat hippocampus," Free Radic. Biol. Med., 48, No. 4, 597-608 (2010).
33. S. H. Liu, C. D. Chang, P. H. Chenand, et al., "Docosahexaenoic acid and phosphatidylserine supplementations improve antioxidant activities and cognitive functions of the developing brain on pentylenetetrazol-induced seizure model," Brain Res., 1451, 19-26 (2012).

34. A. Verrotti, A. Scardapane, E. Franzoniand, et al., "Increased oxidative stress in epileptic children treated with valproic acid," Epilepsy Res., 78, Nos. 2/3, 171-177 (2008).

35. B. D. Obay, E. Tasdemir, C. Tumerand, et al., "Dose-dependent effects of ghrelin on pentylenetetrazole-induced oxidative stress in a rat seizure model," Peptides, 29, No. 3, 448-455 (2008)

36. Y. B. Joshi and D. Pratico, "Vitamin E in aging, dementia, and Alzheimer's disease," Biofactors, 38, No. 2, 90-97 (2012).

37. Q. Zhu, M. A. Emanuele, N. LaPagliaand, et al., "Vitamin E prevents ethanol-induced inflammatory, hormonal, and cytotoxic changes in reproductive tissues," Endocrine, 32, No. 1, 59-68 (2007).

38. A. Dhir, P. S. Naidu, and S. K. Kulkarni, "Effect of cyclooxygenase inhibitors on pentylenetetrazol (PTZ)induced convulsions: Possible mechanism of action," Prog. Neuropsychopharmacol. Biol. Psychiat., 30, No. 8, 1478-1485 (2006).

39. E. S. Akarsu, S. Ozdayi, E. Alganand, et al., "The neuronal excitability time-dependently changes after lipopolysaccharide administration in mice: possible role of cyclooxygenase-2 induction," Epilepsy Res., 71, Nos. 2/3, 181187 (2006).

40. P. Ciceri, Y. Zhang, A. F. Shafferand, et al., "Pharmacology of celecoxib in rat brain after kainate administration," J. Pharmacol. Exp. Ther., 302, No. 3, 846-852 (2002).

41. J. Jourquin, E. Tremblay, N. Decanisand, et al., "Neuronal activity-dependent increase of net matrix metalloproteinase activity is associated with MMP-9 neurotoxicity after kainate," Eur. J. Neurosci., 18, No. 6, 1507-1517 (2003).

42. A. S. Nazrun, M. Norazlina, M. Norlizaand, et al., "The antiinflammatory role of vitamin E in prevention of osteoporosis," Adv. Pharmacol. Sci., 2012, 142702 (2012).

43. C. Rota, G. Rimbach, A. M. Minihaneand, et al., "Dietary vitamin E modulates differential gene expression in the rat hippocampus: potential implications for its neuroprotective properties," Nutr. Neurosci., 8, No. 1, 21-29 (2005).

44. J. Choi, C. C. Conrad, R. Daiand, et al., "Vitamin E prevents oxidation of antiapoptotic proteins in neuronal cells," Proteomics, 3, No. 1, 73-77 (2003).

45. M. Naziroglu, S. Kutluhan, A. C. Uguzand, et al., "Topiramate and vitamin E modulate the electroencephalographic records, brain microsomal and blood antioxidant redox system in pentylentetrazol-induced seizures of rats," J. Membrane Biol., 229, No. 3, 131-140 (2009).

46. N. Crouzin, M. C. Ferreira, C. Cohen-Solaland, et al., "Neuroprotection induced by vitamin E against oxidative stress in hippocampal neurons: involvement of TRPV1 channels," Mol. Nutr. Food Res., 54, No. 4, 496-505 (2010). 